\title{
Right Brain: Should we wear flowers in our hair?
}

Crystal Jing Jing Yeo, MD, PhD, MRCP(UK)

Neurology ${ }^{\circledR}$ 2018;91:761. doi:10.1212/WNL.0000000000006364

\section{Correspondence}

Dr. Yeo

crystaljjyeo@cantab.net

Speak of healing

and freedom and love and peace

Eschew conventions

and expectations and hard-nosed technology

Expand awareness

through mindfulness and meditation and music

Should we wear flowers in our hair

shrug off stiff white coats drop crumpled patient lists

forget statistics and record-keeping the whys and wherefores

who goes on whose list who is on call

Tune in to crescendo tension

of warring chords rocking

primness of white-collar job and profession

squealing under bloated commerce screaming headlines

of physician burnout and despair rising steadily

epidemic swelling year by year

Should we gather the kindred for another summer of love

remember the Hippocratic oath

this is not only a career this is not just a job

our patients are not statistics and we are not numbers

Should we run the revolution confront bayonets with flowers

celebrate another Monterey turn on and sing it

of simplicity of bygone days

of compassion and kindness

of integrity and strength

of one's good name

Remember humanity remember to care

remember to leave the flowers in your hair

\section{Author contributions}

C.J.J. Yeo: drafting/revising the manuscript, accepts responsibility for conduct of research, and will give final approval.

\section{Study funding}

No targeted funding reported.

\section{Disclosure}

C.J.J. Yeo reports no disclosures relevant to the manuscript. Go to Neurology.org/ $\mathrm{N}$ for full disclosures.

From Partners/Brigham and Women's Hospital/Massachusetts General Hospital/Harvard, Boston, MA. 


\title{
Neurology
}

\author{
Right Brain: Should we wear flowers in our hair? \\ Crystal Jing Jing Yeo \\ Neurology 2018;91;761 \\ DOI 10.1212/WNL.0000000000006364
}

This information is current as of October 15, 2018

$\begin{array}{ll}\begin{array}{l}\text { Updated Information \& } \\ \text { Services }\end{array} & \begin{array}{l}\text { including high resolution figures, can be found at: } \\ \text { http://n.neurology.org/content/91/16/761.full }\end{array} \\ \text { Subspecialty Collections } & \begin{array}{l}\text { This article, along with others on similar topics, appears in the } \\ \text { following collection(s): } \\ \text { All Education } \\ \text { http://n.neurology.org/cgi/collection/all_education } \\ \text { Profesional conduct and ethics } \\ \text { http://n.neurology.org/cgi/collection/professional_conduct_and_ethics }\end{array} \\ & \begin{array}{l}\text { Information about reproducing this article in parts (figures,tables) or in } \\ \text { its entirety can be found online at: } \\ \text { http://www.neurology.org/about/about_the_journal\#permissions }\end{array} \\ \text { Permissions \& Licensing } & \begin{array}{l}\text { Information about ordering reprints can be found online: } \\ \text { http://n.neurology.org/subscribers/advertise }\end{array} \\ \text { Reprints } & \end{array}$

Neurology ${ }^{\circledR}$ is the official journal of the American Academy of Neurology. Published continuously since 1951, it is now a weekly with 48 issues per year. Copyright (O 2018 American Academy of Neurology. All rights reserved. Print ISSN: 0028-3878. Online ISSN: 1526-632X.

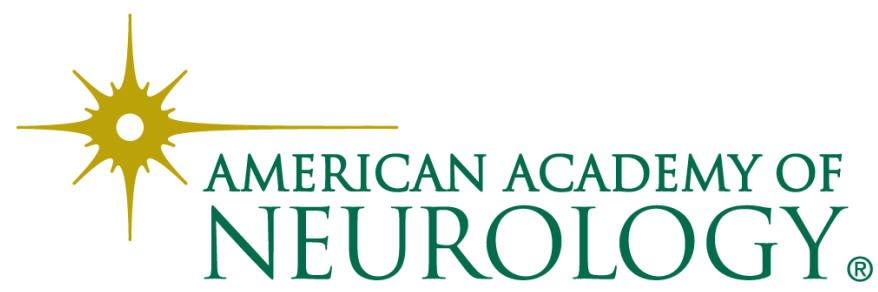

